Agata Dąbrowska

http://dx.doi.org/10.18778/8088-635-3.08

\title{
Żydowski chwast czy most pojednania? Wizerunki teatru żydowskiego w Polsce na łamach prasy polskiej i żydowskiej
}

\begin{abstract}
Niniejszy artykuł omawia różne stereotypowe wizerunki teatru żydowskiego w Polsce prezentowane na łamach prasy polskiej i żydowskiej (w języku polskim i jidysz). Ukazuje wptyw relacji polsko-żydowskich na konstruowanie owych wyobrażeń. Prezentuje zarówno pozytywne, jak i negatywne wizerunki teatru żydowskiego w Polsce.
\end{abstract}

Słowa kluczowe: antysemityzm, Żydzi, teatr żydowski, jidysz, prasa, stereotypy

Termin „teatr żydowski w Polsce” jest pojęciem wieloznacznym. Oznacza zarówno sceny, na których grano w języku jidysz bądź hebrajskim, jak i teatry, gdzie zespoły żydowskie wystawiały sztuki w języku polskim o tematyce żydowskiej bądź z kręgu świeckiej kultury Zachodu. W tym drugim przypadku termin ten ma dwojakie znaczenie. Niektórzy badacze bowiem uważają dorobek literacki i sceniczny Żydów tworzących w języku polskim za ważny element żydowskiego dziedzictwa narodowego. Inni zaś twierdzą, że polskojęzyczny teatr żydowski stanowił integralną część dominującej kultury polskiej. Najobszerniejszą definicję teatru żydowskiego opracował Chone Shmeruk. Zgodnie z jego koncepcją termin ten odnosi się do tworzonych przez Żydów i dla Żydów spektakli w językach: jidysz, hebrajskim i polskim ${ }^{1}$.

Niniejszy artykuł omawia różne stereotypowe wizerunki teatru żydowskiego w Polsce prezentowane na łamach prasy polskiej i żydowskiej (w języku pol-

\footnotetext{
${ }^{1}$ Ch. Shmeruk, Hebrew-Yiddish-Polish. Trilingual Jewish culture, [w:] The Jews of Poland between the world war, red. Y. Gutman, E. Mendelshon i in., Hannover London 1989, s. 283-311.
} 
skim i jidysz) $)^{2}$. Ukazuje wpływ relacji polsko-żydowskich na konstruowanie owych wyobrażeń. W celu pełnego zrozumienia złożoności specyfiki teatru żydowskiego przedstawiono również okoliczności jego narodzin i rozwoju w Polsce.

\section{Narodziny teatru żydowskiego w Polsce}

Zawodowy teatr żydowski narodził się stosunkowo późno, gdyż dopiero pod koniec XIX wieku. Istnieją jednak źródła, które podają, iż przedstawienia w języku jidysz na ziemiach polskich mogły być grane już w latach trzydziestych. Jakub Szacki wspomina o biblijnych spektaklach wystawianych w sali tanecznej szynku „Pod Trzema Murzynami” przed liczną widownią złożoną nie tylko z Żydów, ale i z chrześcijan ${ }^{3}$. Podobne występy odbyły się w Krakowie (1843) i Łodzi (1868) ${ }^{4}$.

Rozkwit żydowskiego życia teatralnego nastąpił w latach osiemdziesiątych XIX wieku i związany był z przyjazdem Warszawy Abrahama Goldfadena ${ }^{5}$. Działalność artystyczna jego zespołu zainspirowała wielu polskich Żydów do stworzenia własnych trup teatralnych ${ }^{6}$. Wystawiały one głównie utwory będące mieszanką farsy i musicalu. Chociaż określano je mianem szundu (kicz, tandeta) ze względu na ich niski poziom artystyczny, to stanowiły one ważną część repertuaru wielu teatrów jidyszowych na ziemiach polskich aż do wybuchu drugiej wojny światowej.

Momentem przełomowym w rozwoju żydowskiego życia kulturalnego było zniesienie obowiązującego na terenie Cesarstwa Rosyjskiego zakazu grania w języku jidysz. Na fali rewolucji 1905 r. powstało wiele nowych zespołów, które rezygnowały z wystawiania kiczowatych operetek na rzecz bardziej ambitnego programu ${ }^{7}$.

\footnotetext{
${ }^{2}$ Ze względu na ograniczoną objętość artykułu w niniejszym opracowaniu pominięto dyskusję dotyczącą roli i miejsca teatru hebrajskiego w Polsce. Zaprezentowano również tylko wybrane koncepcje dotyczące rozwoju teatru żydowskiego w Polsce.

3 J. Szacki, Najstarsze dzieje żydowskiego teatru $w$ Warszawie, thum. T. Kuberczyk, „Pamiętnik Teatralny" 1992, nr 1-4, s. 175-186.

${ }^{4}$ Zob. A. Kuligowska-Korzeniewska, Pierwsze przedstawienia żydowskie w Łodzi, [w:] Lódzkie sceny żydowskie, red. M. Leyko, Łódź 2000, s. 15-38.

5 Abraham Goldfaden (1840-1908) - dramatopisarz i poeta, tworzący w językach jidysz i hebrajskim; autor około pięćdziesięciu sztuk, inspirowanych głównie folklorem żydowskim. Zob. M. Taub, Abraham Goldfaden i teatr żydowski, thum. S. Wojnicki, ,Pamiętnik Teatralny” 1992, nr 1-4, s. 57-70.

${ }^{6} \mathrm{~W}$ tym kontekście należy wymienić Mojsze Isz Halewi Hurwica (Horowitza) (1844-1910) i Nachuma-Meira Szajkiewicza (pseudonim Szomer, 1847/1849-1905). Pierwszy z nich występował w 1887 r. ze swoją trupą w Galicji, zaś Szomer osobiście nadzorował wystawienie swoich sztuk w Łodzi, Warszawie i Wilnie.

7 Zaczęto wystawiać dramaty młodych pisarzy żydowskich, m.in. Szaloma Asza, Dawida Pińskiego, Jakuba Gordina i Szolema Alejchema.
} 


\section{Żydowski chwast}

Powstanie teatru żydowskiego, w szczególności wystawiającego utwory w języku jidysz, z początku spotkało się z negatywnymi reakcjami ze strony polskiej i żydowskiej. Bardzo krytyczne wobec jego rozwoju było środowisko skupione wokół warszawskiego tygodnika „Izraelita"8. Na jego łamach lansowano pogląd, że teatr jidyszowy był jednym z podstawowych czynników zagrażających pełnej asymilacji Żydów z Polakami ${ }^{9}$. Określano go mianem ,złachmanionej sztuki getta"10 bądź „sztuki w szwargocie"11, poddając w wątpliwość poziom artystyczny występujących w nim aktorów:

Grupy teatralne żydowskie składają się z najprzeróżniejszych indywiduów. Począwszy od poważnej pary małżeńskiej, która viribus unitis poświęca się sztuce dramatycznej, a skończywszy na łobuzach, których nędza lub lenistwo do pracy wygnało z domu - znajdziemy tu najróżniejsze żywioły ${ }^{12}$.

Przeciwnicy teatru jidyszowego twierdzili, że - zamiast szerzyć dobre obyczaje - wyzwalał on w ludziach dzikie instynkty. Oburzeni recenzenci donosili, że widzowie, wśród których przeważała biedota, wdzierali się na spektakle siłą, kłócili o miejsca, a podczas przedstawień spożywali kiełbasy i gęsinę. Niejednokrotnie musiała również interweniować policja, by zapanować nad rozwścieczonym tłumem. W ten sposób zakończyła się premiera Szulamis (1897) w ogródku Selina w Łodzi. Rozszalały tłum pobił wówczas kasjera, poturbował woźnych, podeptał klomby i połamał sztachety ${ }^{13}$.

Prezentowany na łamach „Izraelity” wizerunek teatru jidyszowego przyczynił się do wykreowania jego negatywnego stereotypu jako instytucji promującej nieambitną sztukę skierowaną do prostego widza, która pogłębia różnice kulturowe. Pogląd ten lansowano również w polskiej prasie prawicowej, gdzie przekonywano o konieczności zwalczania „teatru żargonowego" "14, uznając go za

\footnotetext{
${ }^{8}$ Zob. M. Bułat, Teatr żydowski w świetle „Izraelity” w latach 1883-1905, „Pamiętnik Teatralny” 1992, zeszyt 1/4, s. 77-126.

${ }^{9}$ Red., Korespondencja ,Izraelity”, „Izraelita” 1883, nr 36, s. 292

${ }^{10}$ [b.a.], Co o nas pisza, ,Izraelita” 1905, nr 42, s. 494.

${ }^{11}$ [b.a.], b.t., „Izraelita” $1886, \mathrm{nr} 8$, s. 60

12 J. Suesser, Kilka słów o żargonie i teatrze żydowskim, „Izraelita” 1890, nr 25, s. 245-246; tegoż, Kilka stów o żargonie i teatrze żydowskim (ciag dalszy), „Izraelita” 1890, nr 26, s. 255-256; tegoż, Kilka stów o żargonie i teatrze żydowskim (dokończenie) „Izraelita” 1890, $\mathrm{nr}$ 27, 266-267.

13 [b.a], Koto, „Izraelita” 1897, nr 22, s. 8.

${ }^{14}$ Ten termin funkcjonuje w publicystyce od połowy XIX w. Używany był przez zwolenników asymilacji, dziennikarzy postulujących zastąpienie jidysz językiem kraju zamieszkania oraz syjonistów traktujących hebrajski jako język narodowy Żydów (M. Adamczyk-Garbowska,
} 
element rozkładowy kultury polskiej i uniemożliwiający jej pełne odrodzenie. Teodor Jeske Choiński przestrzegał w „Kraju” i „Głosie Warszawskim”, że teatr jidyszowy walczy z polskością i wypiera ją ze „sfer żydowskich, pogłębiając separatyzm i nienawiść do wszystkiego, co polskie i chrześcijańskie”, ${ }^{15}$. W „Gazecie Warszawskiej” przyznano zaś, że każdy naród ma prawo do uprawiania sztuki w języku ojczystym, ale jednocześnie stawiano pytanie, co ,żargon żydowski - będący klejonką łamanej niemieckiej, rumuńskiej i małorossyjskiej mowy ma wspólnego z polskim żydostwem"16.

Narodowcy nawoływali do bojkotowania przedstawień żydowskich, które ich zdaniem promowały jedynie zepsucie. Sprawozdawca „Postępu”, dziennika, którego misją było „występowanie w obronie ludu polskiego, chrześcijańskiego i katolickiego przed wyzyskiem żydowskim" " zamiast krzewić oświatę „tonie w bagnisku ciemnoty, przesadów i pogardy dla chrześcijan"18. Dziwił się również, że władze Warszawy wydzierżawiły najładniejsze budynki zespołom żydowskim w dzielnicach zamieszkałych głównie przez Polaków ${ }^{19}$.

Na zmianę negatywnego wizerunku teatru żydowskiego nie wpłynął również fakt wprowadzenia do jego repertuaru dzieł Szekspira. Wystawienie w jednym z warszawskich teatrów Hamleta jeszcze bardziej utwierdziło recenzentów w przekonaniu, że „sceny żargonowe” nie zasługują na miano świątyni sztuki. W zamieszczonym w ,Ziemi Lubelskiej” artykule czytamy:

W jednym $\mathrm{z}$ teatrów żargonowych w Warszawie wystawiono po raz pierwszy „Hamleta”. Jak wyglądało to arcydzieło Szekspira w języku Jackanów świadczy recenzja zamieszczona $\mathrm{w}$ jednym z pism żargonowych. „Na scenie - pisał recenzent - widziano coś czego nie widziano na żadnem innem widowisku... tłómaczenia dokonał ktoś, co nie rozumiał wcale treści „Hamleta”... nikt ze słuchaczów ani słowa nie rozumiał... aktorzy również”... Tych kilka zdań daje pojęcie jak wyglądał ten żargonowy „Hamlet” ${ }^{20}$.

Odcienie tożsamości. Literatura jako zjawisko wielojęzyczne, Lublin 2004, s. 8). Pojawiał się także w międzywojennym dyskursie antysemickim. Termin "teatr żargonowy” miał zazwyczaj wydźwięk negatywny, oparty na przekonaniu, że jidysz jest zniekształconą odmianą niemczyzny. Określenie to bywało również traktowane jako synonim teatru żydowskiego (jidyszowego). Zob.

M. Korenfeld, Ghettowcy, Warszawa 1916, s. 11-14.

${ }^{15}$ T. Jeske-Choiński, Teatr żydowski, „Głos Warszawski” 1908, nr 160, s. 2.

${ }^{16}$ [b.a.], Teatr żydowski, „Gazeta Warszawska” 1885, nr 16, s. 2.

${ }^{17}$ Nik., Warszawskie żydki, „Postęp” 1907, nr 152, s. 1.

${ }^{18}$ Tamże.

${ }^{19}$ Tamże.

${ }^{20}$ [b.a], ,,Hamlet” żargonowy, „Ziemia Lubelska” 1913, nr 182, s. 3. 
Teatr jidyszowy był zdaniem polskich komentatorów miejscem niebezpiecznym, gdzie można było zostać okradzionym. Zdarzało się także często, że spektakle wystawiane w języku jidysz stawały się pretekstem do urządzania bójek i demonstracji antypaństwowych. Przykładowo, podczas premiery Kary śmierci $\mathrm{w}$ Teatrze Scala $\mathrm{w}$ Warszawie doszło do przepychanek na widowni między lewicowymi anarchistami a policją. Spektakl zakończył się masowymi aresztowaniami demonstrantów, którzy zakłócili jego przebieg wykrzykując hasła antyrządowe ${ }^{21}$.

Niechęć do teatru jidyszowego w Polsce nasiliła się w dwudziestoleciu międzywojennym. Przed teatrami organizowano pikiety antyżydowskie, które kończyły się interwencją policji. Podczas jednej z takich demonstracji, zorganizowanej w 1935 r. w Bielsku, Żydów poturbowano i oblano kwasem solnym. Krytycy związani z narodową demokracją traktowali recenzje teatralne jako pretekst do prezentowania skrajnych poglądów antysemickich. Pisali, że „sztuka żydowska” to „pomiot”, ,kicz” bądź ,żydowski chwast”. Publikowali listy nazwisk tzw. „kryptożydów”, czyli artystów żydowskich, którzy tworzyli po polsku - np. Arnolda Szyfmana, reżysera żydowskiego pochodzenia, okrzyknięto po premierze Hamleta (1939) „pierwszym Żydem Rzeczpospolitej”,22 oraz „funkcjonariuszem anonimowego mocarstwa, które wypowiedziało Polsce śmiertelną wojnę"23.

\section{Most pojednania polsko-żydowskiego}

Żydowskie środowiska teatralne zdecydowanie protestowały przeciwko propagowaniu w Polsce negatywnego wizerunku teatru żydowskiego. Proponowały utworzenie teatru, który określano mianem forum polsko-żydowskiego dialogu kulturalnego, gdzie starano się przełamywać wzajemne uprzedzenia i stereotypy. Miało być to miejsce zwalczania tzw. ,artystycznego antysemityzmu”. Za autora i głównego realizatora tej koncepcji uważa się Andrzeja Marka ${ }^{24}$. Stworzył on polskojęzyczny teatr żydowski, w którym wystawiał dramaty jidysz w swoim tłumaczeniu, by - jak twierdził - zapoznać Polaków ze światowym kanonem literatury żydowskiej.

W wywiadzie udzielonym łódzkiej „Republice” przed premierą Mirele Efros tłumaczył, że „utwór ten zapoczątkował systematyczną moją działalność

\footnotetext{
${ }^{21}$ [b.a], Nieudane prowokacje komunistów, „Nowiny Codzienne” 1933, nr 224, s. 3.

${ }^{22}$ S. Piasecki, ,Hamlet” $i$, Cyrulik sewilski”, „Prosto z mostu” 1939, nr 16, s. 8.

${ }^{23}$ Tamże.

${ }^{24}$ Andrzej Marek (właściwie Marek Arnstajn lub Arenstajn, 1880-1943) - dramatopisarz oraz reżyser teatralny i filmowy. Podczas drugiej wojny światowej przebywał w getcie warszawskim, gdzie był kierownikiem literacko-artystycznym w grającym w języku polskim Nowym Teatrze Kameralnym. Zginął w 1943 r. podczas likwidacji getta albo w komorze gazowej w Treblince.
} 
zaznajamiania społeczeństwa polskiego z duszą i życiem narodu żydowskiego. [...] Idei tej poświęcam całe swe życie i mam wrażenie, że życia nie marnuję"25.

Nadrzędnym celem działalności scenicznej Marka była próba doprowadzenia do pojednania narodu polskiego i żydowskiego. „Pragnę być w teatrze nie tylko reżyserem ale i obywatelem” - dowodził reżyser ${ }^{26}$. „Podczas wojny każdy człowiek obowiązany jest być żołnierzem; podczas pokoju każdy winien walczyć o pokojowe współżycie narodów i ras, o dobra kulturalne, o sprawiedliwość. O te ideały walczę w teatrze jako autor dramatyczny, jako inscenizator i reżyser!,27.

Marek twierdził jednak, że jego teatr miał przede wszystkim charakter społeczny:

Teatr, o którym marzę, winien grywać wyłącznie utwory o charakterze społecznym. Oczywiście walory artystyczne są również dla tych utworów warunkiem sine qua non. Marzę o teatrze, któremu będzie dane spełnić podniosłą misję pojednania narodów, ras i klas. Marzę o artystycznej platformie dla systematycznej i godziwej propagandy pokoju, tolerancji i wzajemnego miłowania się ludzi bez względu na to, do jakiego Boga się modlą i w jakim języku swoje smutki i radości wyrażają. Marzę o scenie, na której wzniosie duchy będą zwalczać ciemnotę, ignorancję i nienawiść we wszystkich jej objawach! $!^{28}$

Poglądy Marka i jego działalność misyjna spotkały się z aprobatą środowisk żydowskich, związanych z „Naszym Przeglądem”. Zwracano uwagę, że w przeciwieństwie do polskiej literatury w teatrze polskim panował kompletny asemityzm lub antysemityzm. Utwory o tematyce żydowskiej albo nie były wystawiane, albo prezentowały stereotypowy wizerunek Żyda lichwiarza i krwiopijcy. Teatr polsko-żydowski miał zatem stać się miejscem zwalczania wzajemnych uprzedzeń:

Oto dlaczego potrzebny nam jest teatr polsko-żydowski. Jego repertuar składać się może niekonieczne tylko ze sztuk tłumaczonych z żydowskiego. Ileż jest w repertuarze światowym sztuk osnutych na tle żydowskim, których się w Polsce tendencyjnie nie gra! Iluż autorów (żydów i nieżydów) napisałoby po polsku takie sztuki, gdyby wiedzieli, że one się ukażą na scenie. Wreszcie teatr taki ukaże swoim i obcym dość bogaty poczet dzieł napisanych po żydowsku i po hebrajsku. To ostatnie zachęci z jednej strony inteligencję żydowską do ujrzenia tych samych utworów

\footnotetext{
${ }^{25}$ Ego., Przed premjera „,Miry Efros”. Rozmowa z Andrzejem Markiem, „Republika” 1929, nr 169, s. 4.

${ }^{26}$ [b.a], Mirele Efros” na polskiej scenie, „Chwila” 1929, nr 3711, s. 5.

${ }^{27}$ Tamże.

${ }^{28}$ A. Marek, Wyjaśnienie p. Marka, ,Nasz Przegląd” 1929, nr 207, s. 8.
} 
granych $\mathrm{w}$ oryginale, a $\mathrm{z}$ drugiej może przekonać bezstronnych polaków, że teatr żydowski (i hebrajski) godne są poparcia ${ }^{29}$.

Podobne zdanie w tej kwestii wyraził J. Podskocz, dowodząc, że teatr polsko-żydowski mógłby się przyczynić do wzrostu zainteresowania żydowskiej młodzieży repertuarem jidyszowym. Dzięki niemu bowiem widzowie mieli sobie uświadomić, iż ,istnieje bogata literatura żydowska, dramat żydowski i lepiej go ujrzeć w oryginale na żydowskiej estradzie, niż na obcej scenie". Teatr polsko-żydowski, zdaniem krytyka, stanowił most, po którym młodzież żydowska miała thumnie powrócić do swoich korzeni ${ }^{30}$.

$\mathrm{W}$ walkę $\mathrm{w}$ przełamywaniu wzajemnych negatywnych stereotypów na gruncie teatru włączył się czynnie Jakub Appenszlak ${ }^{31}$. Wierzył, że Żydzi mieli pełne prawo do budowania swojej kultury nie tylko w języku jidysz czy hebrajskim, ale również po polsku. W jednym ze swoich programowych poematów pisał: „O mowo polska! Ty jesteś także moją mową, mową Żyda, /co na brzegach Wisły o Syjonie marzy..." ${ }^{32}$. Appenszlak - jak pisał o nim Leo Finkelstein - ,kulturę polską nosił we własnej krwi, a kulturę żydowską w swej świadomości poetyckiej”33.

Appenszlak wierzył w pojednanie narodu polskiego i żydowskiego na gruncie teatru, przy jednoczesnym zachowaniu przez Żydów własnej tożsamości i dziedzictwa narodowego, o czym wielokrotnie przekonywał na łamach „Naszego Przeglądu":

W braciach narodu naszego chcemy spotęgować poczucie narodowe, rozszerzyć świadomość mocy twórczej i dóbr duchowych żydostwa. Społeczeństwu polskiemu pragniemy udostępnić zrozumienie naszej jaźni narodowej, jej praw i ideałów. Jako obywatele Rzeczypospolitej chcemy Polski silnej i trwałej, wolnej i wolnością darzącej, potęgę swą i dobrobyt czerpiącej ze zgodnej współpracy wszystkich obywateli, bez względu na wyznanie, narodowość lub poglądy ${ }^{34}$.

Ważną rolę w realizacji owego celu miał odgrywać teatr. Appenszlak postulował utworzenie teatru polsko-żydowskiego, ,teatru dobrej woli”, w repertuarze

\footnotetext{
${ }^{29}$ M. Friszlender, Czy potrzebny jest teatr polsko-żydowski. Artykut dyskusyjny, „Nasz Przegląd” 1929, nr 236, s. 7.

30 J. Podskocz, Czy potrzebny jest teatr polsko-żydowski. Artykut dyskusyjny, „Nasz Przegląd” 1929, nr 256, s. 4.

${ }^{31}$ Jakub Appenszlak (1894-1950) - publicysta, prozaik, thumacz, krytyk literacki i teatralny.

32 J. Szacki, , ,Zloty Róg”, „Nasza Trybuna” 1950, nr 3, s. 10.

${ }^{33}$ L. Finkelstein, Oblicze literackie Jakuba Appenszlaka, „Nasza Trybuna” 1950, nr 3, s. 10.

${ }^{34}$ [b.a.], Na posterunku, „Nasz Przegląd” 1923, nr 1, s. 1.
} 
którego miały się znaleźć utwory o tematyce żydowskiej ${ }^{35}$. Jednocześnie podkreślał, że nie będzie on zagrażał scenom jidyszowym, gdyż, jak dowodził, „można śmiało prowadzić stały teatr żydowski po polsku. A teatr taki odpowiada żywotnej potrzebie i może się utrzymać obok teatru jidyszowego, jak pismo polsko-żydowskie istnieje obok prasy żydowskiej" ${ }^{\prime 36}$.

Appenszlak ubolewał, że polska krytyka omijała „teatr żydowski, choćby gościła w nim prawdziwa sztuka" ${ }^{37}$, ponieważ był on jej obcy bardziej niż kultura $\mathrm{Chin}^{38}$. Dziennikarz pragnął, by kultura żydowska stała się interesująca, a zarazem dostępna również dla Polaków, dlatego tłumaczył na język polski dzieła wybitnych dramatopisarzy żydowskich, m.in. Szolema Alejchema i Szaloma Asza.

\section{Symbol odrodzenia narodu żydowskiego}

Zagorzała debata na temat roli i miejsca teatru żydowskiego w kulturze polskiej stała się jednym z głównych problemów dyskutowanych na łamach prasy polsko- i żydowskojęzycznej w latach trzydziestych XX wieku. Zainicjowały ją dwie ankiety zamieszczone w dziennikach „Der Moment” i „Folksblat”, w których zadano pytania: „,czy teatr żydowski powinien być «czysto jidyszowy» czy też światowy?” oraz „czy nie nadszedł już czas usunięcia kapoty z żydowskiej sceny i czy w ogóle jest to możliwe?".

Głos w kwestii przyszłości teatru żydowskiego zabrali wszyscy przedstawiciele środowisk artystycznych w Polsce, prezentując wzajemnie się wykluczające rozwiązania. Mojżesz Kanfer, dziennikarz i krytyk literacki, uważał, że niechęć do występów trup żydowskich związana była przede wszystkim z upowszechnianiem stereotypu jidysz jako żargonu, a nie języka narodowego mniejszości żydowskiej ${ }^{39}$. Zdawał sobie jednak sprawę, że wraz z postępującymi procesami akulturacji i asymilacji, kultura żydowska będzie stawała się wielojęzyczna. Przekonania Kanfera spotkały się z ostrym sprzeciwem kręgów jidyszystycznych, które ochrzciły go mianem „grabarza żydowskiej kultury i literatury" ${ }^{40}$.

\footnotetext{
35 Pierrot, Między wierszami. Czy powinien istnieć teatr „polsko-żydowski”, „Nasz Przegląd” 1929 , nr 272, s. 5.

${ }^{36}$ Zastępca, Scena polsko-żydowska, „Nasz Przegląd” 1929, nr 203, s. 6.

${ }^{37}$ J. Appenszlak, ,Opowieść o siedmiu powieszonych” w Teatrze „Centralnym”, „Nasz Przegląd” 1923 , nr 66, s. 3.

${ }^{38}$ J. Appenszlak, Scena polska, „Nasz Przegląd” 1925, nr 147, s. 3.

39 M. Kanfer, Kiedy wreszcie przestaniemy mówić o ,żargonie żydowskim”? Na marginesie recenzji z przedstawień Trupy Wileńskiej, „Nowy Dziennik” 1931, nr 121, s. 11.

${ }^{40}$ M. Kanfer, Kilka słów odpowiedzi wileńskiemu Togowi, „Nowy Dziennik”, 1928, nr 348, s. 3; E. Prokop-Janiec, Mojżesz Kanfer a teatr jidysz, [w:] Teatr Żydowski w Krakowie. Studia i materiaty, red. J. Michalik, E. Prokop-Janiec, Kraków 1995, s. 128-129.
} 
Sam Kanfer nazywał siebie „orędownikiem teatru żydowskiego "41 , „rozmiłowanym w języku jidysz"42.

W licznych artykułach publikowanych głównie w „Nowym Dzienniku” mówił on o konieczności podniesienia poziomu artystycznego ${ }^{43}$, unowocześnienia i zeuropeizowania żydowskiej sceny, przy jednoznacznym zachowaniu jej ludowych źródel ${ }^{44}$. „My Żydzi mamy już dość Dybuków i innych misteriów chasydzkich” - grzmiał na łamach „Nowego Dziennika” - „Chcemy mieć teatr europejski, to jest nie cofający się przed żadną konfrontacją z rzeczywistością" 45 .

W podobny sposób o teatrze żydowskim wyrażał się Michał Weichert. Pisał, że pomysł wystawiania w nim tylko sztuk o tematyce żydowskiej był absurdalny, ponieważ środowisko, w którym toczy się akcja dramatu nie determinuje jego charakteru narodowego ${ }^{46}$. Podkreślał przy tym, że wiele utworów pisanych w języku jidysz opartych jest na motywach zaczerpniętych z dzieł należących do światowego kanonu:

Kiedy ja czytam i wybieram sztukę do wystawienia żydowskość teamu odgrywa u mnie znikomą rolę. Myślę o różnych zaletach sztuki - o żydowskim środowisku najmniej i na samym końcu. To nie jest przypadek, że sztuki narodzone z obcego ducha albo napotkały na opór żydowskiej publiczności, albo przynajmniej nie znajdowały drogi do jej serca ${ }^{47}$.

Stanowiska Weicherta i Kanfera nie podzielali jednak ortodoksyjni jidyszyści. Jeden z ich czołowych przedstawicieli, Naftali Weinig, krytyk literacki, w swoim eseju Mity Jidyszyzmu (1932) stwierdzil, że współczesna kultura jidysz potrzebuje mitu, który „będzie nie tylko uosobieniem lub wcieleniem idei ruchu, ale będzie również służyć jako mapa, zachęcająca i stymulująca działania zarówno na poziomie osobistym, jak i interpersonalnym, dając jidyszyzmowi uzasadnienie i podstawę do

\footnotetext{
${ }^{41}$ M. Kanfer, O sanację teatru żydowskiego w Polsce, „Nowy Dziennik” 1931, nr 139, s. 10-11.

${ }^{42}$ M. Kanfer, Żydowski Teatr Artystyczny. „Opowieść o siedmiu powieszonych” L. Andrejewa, „Nowy Dziennik” 1924, nr 140, s. 3.

${ }^{43}$ E. Prokop-Janiec, dz. cyt., s. 125.

${ }^{44}$ M. Kanfer, Abraham Goldfaden. W 30-lecieśmierci, „Nowy Dziennik” 1938, nr 65, s. 6; E. Prokop-Janiec, dz. cyt., s. 133.

${ }^{45}$ M. Kanfer, Gościnne występy Trupy Wileńskiej ,,Święty płomień” Somerset Maughana. Reż. J. Szigarin, „Nowy Dziennik” 1931, nr 119.

${ }^{46}$ M. Bułat, Trójjęzyczny teatr żydowski w Polsce „,w lustrze” publicystyki Michała Weicherta na tamach „Lirerarisze Bleter” (Wprowadzenie), [w:] Żydzi w lustrze dramatu, teatru i krytyki teatralnej, red. E. Udalska, Katowice 2004, s. 271-272.

${ }^{47}$ M. Weichert, Jidiszkejt in teatrer, tłum. M. Bułat, „Literarisze Bleter” 1930, nr 35, s. 655.
} 
istnienia $^{48}$. Rolę taką miał właśnie odgrywać teatr jidyszowy, stając się symbolem odrodzenia narodowego i duchowego Żydów. Pogląd taki reprezentował m.in. Jecheskiel Mojsze Najman przekonując, że artyści żydowscy powinni tworzyć w swoim własnym języku, ponieważ są suwerennym narodem, a nie Polakami wyznania mojżeszowego ${ }^{49}$. Podobne zdanie $\mathrm{w}$ tej kwestii wyrażał także Zygmunt Turkow ${ }^{50}$, założyciel i główny reżyser Warszawskiego Żydowskiego Teatru Artystycznego. Artysta pragnął, żeby jego teatr strzegł żydowskiej spuścizny narodowej, będąc ,żydowskim z ducha i formy" ${ }^{\text {" }}$ :

Teatr żydowski nie może być inny od życia żydowskiego, musi mieć w sobie i głębię i lekkość, i zadumę i skoczność, musi być rozśpiewany i roztańczony, pełen łez i pełen pieśni. A taki jest właśnie teatr goldfadenowski. Znajdzie pan w nim i patos bohaterstwa narodowego jak w „Bar Kochbie” i słodycz miłości jak w „Sulamit”, a nawet w jego ówczesnych sztukach ,z tezą", w sztukach przesiąkniętych haskalą odkryć można niewyczerpane bogactwo motywów ściśle teatralnych. Rozumie się samo przez się, że te ówczesne dygresje polityczno-społeczne można albo wyrzucić albo je uwspółcześnić, ale ten teatr zawsze żyje i zawsze przemawiać będzie do żydów ${ }^{52}$.

\section{Ryba po żydowsku}

Poglądy reprezentowane przez Najmana i Turkowa przyczyniły się pośrednio do wykreowania wizerunku teatru o bardzo ograniczonym repertuarze. Popularne stało się porzekadło, że do teatru żydowskiego (jidyszowego) chodzi

\footnotetext{
${ }^{48}$ N. Weining, Mity jidyszyzmu, „Miesięcznik Żydowski” 1932, s. 532.

49 J. M. Najman, ,, Der gojlem” po polsku, „Hajnt” 1928, nr 128, s. 9.

${ }^{50}$ Utworzeniu teatru żydowskiego $\mathrm{w}$ języku polskim lub $\mathrm{w}$ innych językach nie-żydowskich przeciwstawiał się także Jonas Turkow, żydowski aktor i reżyser. Zwracał uwagę, że z powodu trudnej sytuacji finansowej i lokalowej sceny żydowskie nie były w stanie konkurować z teatrem polsko-żydowskim, co w konsekwencji doprowadziłoby do ich zamknięcia. Popierał natomiast tłumaczenie dzieł żydowskich na języki obce uważając, że dzięki temu dotrą one do szerszego grona odbiorców. Literatura żydowska w przeciwieństwie do teatru - argumentował reżyser - wywalczyła sobie samodzielność na arenie międzynarodowej. Turkow był jednym z najbardziej zagorzałych przeciwników Andrzeja Marka. Do ostrej wymiany zdań miedzy reżyserami doszło na łamach „Literarisze Bleter”. Zob. J. Turkow, Jidisz teatre on jidisz, „Literarisze Bleter” 1929, nr 33, s. 641; M. Arnsztajn, Wi ich ze dos, „Literarisze Bleter” 1929, nr 35, s. 688-689; J. Turkow, Di 'kemfer' far jidiszer kultur, „Literarisze Bleter” 1929, nr 36, s. 1-2.

${ }^{51}$ Reżyser zmienił swoje podejście do teatru jidyszowego pod koniec lat trzydziestych XX wieku. Wcześniej był jednym z głównych orędowników jego otwarcia na dramaturgię europejską. Zob. M. Bułat, W poszukiwaniu teatru „żydowskiego": Zygmunt Turkow, [w:] Antreprener. Księga ofiarowana profesorowi Janowi Michalikowi w 70. rocznicę urodzin, red. J. Popiel, Kraków 2009, s. 585-605.

${ }^{52}$ M.K., Teatr Goldfadenowski - teatrem żydowskim. Z rozmowy z Zygmuntem Turkowem, „Nowy Dziennik" 1939, nr 107, s. 8.
} 
się na sztuki tradycyjnie żydowskie, tak jak do restauracji żydowskiej na „rybę po żydowsku".

Stworzenie tego stereotypu odbiło się bardzo niekorzystnie na kondycji teatru jidysz i wielokrotnie doprowadzało do kuriozalnych sytuacji. Tadeusz BoyŻeleński odmówił m.in. obejrzenia Kupca weneckiego w reżyserii Weicherta, tłumacząc, że chciał „zobaczyć coś waszego”. Reżyser poczuł się urażany, tym bardziej, że inscenizacja ta uchodziła za jedną z najlepszych adaptacji dzieła Szekspira ${ }^{53}$. Wypowiedź Boya skwitował słowami: „Gdyby teatr żydowski miał się liczyć z tym wspomnianym rodzajem konsumenta, byłby może chwilowo dobrym interesem, ale nie ogniwkiem świeckiej kultury jidysz" ${ }^{\prime 54}$.

Niejednokrotnie recenzenci wyrażali dezaprobatę i oburzenie, kiedy na scenie żydowskiej wystawiano dramaty autorów nie-żydowskich. Przykładowo, Artur Sandauer protestował przeciwko premierze Pana Jowialskiego Aleksandra Fredry, twierdząc, że w teatrze jidysz „nie powinno się w ogóle wystawiać sztuk, które nie mają nic wspólnego z życiem żydowskim. Mowa żydowska w ustach króla czy szlachcica brzmi dziwnie" - jak dalej argumentował - „gdyż postaci takich w tym narodzie nie było" ${ }^{\text {"5 }}$. Lucjan Kydryński zaś mawiał, że aktorzy żydowscy powinni ograniczać się tylko do „specyficznego” repertuaru. Ida Kamińska, reżyserka spektaklu, nie pozostała bierna wobec powyższych stwierdzeń,

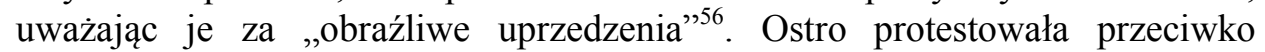
zamykaniu jej sceny tylko w kręgu kultury jidysz. „Chcemy być” - pisała na łamach „Teatru” - „zachowując naszą specyfikę, język i temperament - jeszcze jednym dobrym teatrem w Polsce" ${ }^{57}$. Potwierdzeniem tego, w jej przekonaniu, miała być premiera Pana Jowialskiego. Kamińska zaprezentowała utwór w zupełnie nowej odsłonie, uwalniając go ze wszelkich kontekstów narodowych i sielskiej atmosfery życia codziennego. Pan Jowialski w jej ujęciu nie był klasyczną komedią, lecz dramatem naturalistycznym.

Postulowana przez ortodoksyjnych jidyszystów izolacja teatru jidyszowego w Polsce powodowała, że jego repertuar uchodził za przestarzały. „Teatr czulentowy" - jak go określił Weichert - nie miał w sobie nic profesjonalnego, ponieważ zaspokajał jedynie „folklorystyczne sentymenty i gusta publiczności rozmiłowanej w tańcu i śpiewach" ${ }^{, 5}$. Przeciwko izolowaniu teatru jidysz w getcie kulturalnym protestowali również dziennikarze „Wiadomości Literackich”.

\footnotetext{
${ }^{53}$ M. Bułat, Trójjęzyczny teatr..., s. 274.

${ }^{54}$ M. Weichert, dz. cyt., s. 655.

55 A. Sandauer, Na marginesie „, Snu o Goldfadenie”, „Przegląd Kulturalny” 1954, nr 50, s. 5.

${ }^{56}$ L. Kydryński, Odwiedziny teatralne, „Przekrój” 1955, nr 526, s. 11.

${ }^{57}$ I. Kamińska, Nieporozumienia, „Teatr” 1955, nr 12, s. 18.

${ }^{58}$ M.K., Pod adresem p. Díeni Lowicz i p. Lewina, „Nowy Dziennik” 1938, nr 198, s. 9.
} 
Czołowy recenzent tygodnika, Antoni Słonimski, twierdził, że „duch czasu inne stawia wymagania":

Ludzie współcześni w każdym narodzie łączyć się muszą przeciw ludziom ciemnym. Toteż bolesne jest, że ci, którzy u nas stać powinni w czołowych szeregach postępu zaprzedają się ciemnocie. Nie podnoszą getta, ale sami się w nie staczają ${ }^{59}$.

Przykładem dla teatru jidyszowego miała być Habima, której poziom artystyczny - zdaniem krytyka - przewyższał niekiedy i scenę polską. Recenzując Zemstę w reżyserii Zygmunta Chmielewskiego, Słonimski pisał: „Bodaj od gościnnych występów Habimy nie oglądała Warszawa takiej pracy zespołu, a zwłaszcza tak artystycznych dekoracji” ${ }^{\prime 0}$. Doceniał on pracę Andrzeja Marka na rzecz tworzenia teatru żydowskiego w języku polskim, natomiast konsekwentnie ignorował repertuar scen jidyszowych. Wspomniał tylko raz o cieszącej się sporym sukcesem inscenizacji Dybuka w wykonaniu Trupy Wileńskiej: „Podobno wileńscy aktorzy żydowscy grali Dybuka kapitalnie, z dynamiką i precyzją aktorów chińskich" "61. Pominął zaś milczeniem premierę Burzy w reżyserii Leona Schillera wystawioną przez Folks un Jugnt Theatre w Łodzi, która uznana została zarówno przez polskich, jak i żydowskich sprawozdawców za ważne wydarzenie w przełamywaniu wzajemnych uprzedzeń artystycznych.

\section{Podsumowanie}

Wizerunek teatru żydowskiego prezentowany na łamach prasy polskiej i żydowskiej jest bardzo złożony. Sposób jego postrzegania zależał w dużej mierze od relacji polsko-żydowskich i opierał się na wzajemnych uprzedzeniach.

$\mathrm{Na}$ negatywny stosunek do teatru żydowskiego w Polsce wpływ miało przede wszystkim przekonanie, że wszystko, co żydowskie, jest złe i grzeszne. Teatr postrzegano więc jako wroga zagrażającego kulturze chrześcijańskiej. Uznawano go za niemoralny przybytek, w którym czczono pogańskich bożków, a obecność na przedstawieniach traktowano jako wyraz sprzeniewierzenia się tradycyjnym wartościom.

Podobnie postrzegali teatr ortodoksyjni rabini, uważając aktorów za wcielenie wszelkiego zła, za osoby szydzące, bluźniące i przeklinające Boga. Szcze-

\footnotetext{
${ }^{59}$ A. Słonimski, Kronika tygodniowa, „Wiadomości Literackie” 1929, nr 47, s. 11.

${ }^{60}$ A. Słonimski, ,Zemsta” w Ateneum, „Wiadomości Literackie” 5 października 1930, nr 353, s. 4.

${ }^{61}$ A. Słonimski, Teatr Szkarłatna Maska: „Dybuk”, legenda dramatyczna w 3 aktach Szymona Anskiego; wolny przekład i inscenizacja Andrzeja Marka; reżyserowat tlumacz; dekoracje wykonat Józef Wodyński, „Wiadomości Literackie” 1925, nr 75, s. 5.
} 
gólnie ostro protestowali przeciwko uczestniczeniu w spektaklach, w których grały kobiety. Rabini nauczali bowiem, że głos obcej niewiasty może budzić w mężczyźnie dzikie pożądanie. Niedozwolone było również słuchanie muzyki instrumentalnej, jako wytworu kultury nieżydowskiej ${ }^{62}$. Sprzeciwiano się nadto zakładaniu kostiumów, zwłaszcza tych, które powodowały, że aktor wcielał się w osobę odmiennej płci ${ }^{63}$.

Szczególną niechęć wzbudzał teatr żydowski w języku jidysz. Publicyści skupieni wokół tygodnika „Izraelita” deprecjonowali jidysz jako żargon i żądali zaprzestania tworzenia kultury w tym języku. „Teatr żargonowy” - ich zdaniem - był instytucją nieprofesjonalną i szkodzącą procesowi asymilacji. Niepochlebnie na temat scen jidyszowych wypowiadali się także polscy nacjonaliści, przekonując, że pogłębiają one rozwarstwienie kulturowe. Twierdzili, że Żydzi zamiast uczestniczyć w przedstawieniach o wątpliwym poziomie artystycznym, powinni uczęszczać do teatru polskiego. Ten wizerunek teatru żydowskiego jako wrogiej instytucji związany był $\mathrm{z}$ lansowanym już przed pierwszą wojną światową, a przybierającym na sile w dwudziestoleciu międzywojennym, negatywnym stereotypem Żyda-obcego. Przedstawiciele środowisk endeckich przekonani, że odrębność Żydów przyczynia się do upadku państwa polskiego, postulowali ich całkowite włączenie w życie kulturalne i polityczne kraju. Naród polski zgodnie $\mathrm{z}$ ich teorią miał być jednolity, a więc nie było w nim miejsca dla teatru obcojęzycznego.

W tym samym czasie funkcjonował jednak również pozytywny wizerunek teatru żydowskiego w Polsce. Postrzegany był on jako instytucja nowoczesnej i zarazem świeckiej kultury żydowskiej. Traktowano go jako placówkę społeczną, której nadrzędnym celem było kształtowanie tożsamości narodowej Żydów. Nadano mu po części charakter edukacyjny, ponieważ popularyzował i upowszechniał dorobek polskich Żydów.

Ponadto teatr żydowski (polsko i jidyszowojęzyczny) stał się w dwudziestoleciu międzywojennym symbolem dialogu kulturalnego narodu polskiego i żydowskiego. Miejscem zwalczania tzw. ,artystycznego antysemityzmu”. Szczególną rolę na rzecz pojednania $\mathrm{w}$ dziedzinie sztuki odegrali artyści, którzy

\footnotetext{
${ }^{62} \mathrm{~W}$ traktacie Miszny „Awoda Zara”, zajmującym się problemem idolatrii i obcych kultów, zabroniono chodzenia do cyrków i teatrów, a złamanie tego nakazu wiązało się z oskarżeniem o bałwochwalstwo. Ta niechętna postawa wobec widowisk teatralnych przetrwała do czasów współczesnych, ponieważ w niektórych modlitewnikach można odnaleźć następujący zapis: „Dziękuję ci Boże [...], że nie jestem wśród tych, którzy uczęszczają do teatrów i cyrków”. T. Kuberczyk, Przedstawienia purimowe, „Pamiętnik Teatralny” 1992, nr 1-4, s. 27.

${ }^{63}$ W Księdze Powtórzonego Prawa czytamy: „Kobieta nie będzie nosiła ubioru mężczyzny, a mężczyzna ubioru kobiety”. Tamże, s. 27-29.
} 
wbrew protestom polskich i żydowskich nacjonalistów, zdecydowali się na wzajemną współpracę celem przełamywania wzajemnych uprzedzeń. Należeli do nich m.in. Andrzej Marek, Andrzej Pronaszko, Jan Hawryłkiewicz czy Leon Schiller. Dzięki ich działalności artystycznej dramaty jidysz zaczęto tłumaczyć i wystawiać w teatrach polskich, jak i odwrotnie. Chociażby sztuka Mirele Efros Autorstwa Jakuba Gordina grana była zarówno w języku jidysz, jak i polskim, a w postać głównej bohaterki wcielały się najznakomitsze gwiazdy międzywojennej Polski, m.in. Ester Rachel Kamińska, Lidia Potocka, Wanda Siemaszkowa.

Obecnie teatr żydowski w Polsce pełni bardzo specyficzną rolę. Stał się przede wszystkim miejscem upamiętniania przeszłości naznaczonej masowymi grobami i krematoriami. 


\section{Bibliografia}

Adamczyk-Garbowska M., Odcienie tożsamości. Literatura jako zjawisko wielojęzyczne, Lublin 2004.

Appenszlak J., „, Opowieść o siedmiu powieszonych” w Teatrze „Centralnym”, „Nasz Przegląd” 1923, nr 66, s. 3.

Appenszlak J., Scena polska, „Nasz Przegląd” 1925, nr 147, s. 3.

Arnsztajn M., Wi ich ze dos, „Literarisze Bleter” 1929, nr 35, s. 688-689.

[b.a.], b.t., „Izraelita” 1886, nr 8, s. 60

[b.a.], Co o nas pisza, ,Izraelita” 1905, nr 42, s. 494.

[b.a.], Na posterunku, „Nasz Przegląd” 1923, nr 1, s. 1.

[b.a.], Teatr żydowski, „Gazeta Warszawska” 1885, nr 16, s. 2.

[b.a], ,Hamlet” żargonowy, „Ziemia Lubelska” 1913, nr 182, s. 3.

[b.a], Koło, „Izraelita” 1897, nr 22, s. 8.

[b.a], Mirele Efros” na polskiej scenie, „Chwila” 1929, nr 3711, s. 5.

[b.a], Nieudane prowokacje komunistów, „Nowiny Codzienne” 1933, nr 224, s. 3.

Bulat M., Teatr żydowski w świetle „Izraelity” w latach 1883-1905, „Pamiętnik Teatralny” 1992, zeszyt 1/4, s. 77-126.

Bułat M., Trójjęzyczny teatr żydowski w Polsce „w lustrze” publicystyki Michała Weicherta na łamach „Lirerarisze Bleter” (Wprowadzenie), [w:] Żydzi w lustrze dramatu, teatru i krytyki teatralnej, red. E. Udalska, Katowice 2004, s. 269-280.

Bułat M., W poszukiwaniu teatru „żydowskiego": Zygmunt Turkow, [w:] Antreprener. Ksiega ofiarowana profesorowi Janowi Michalikowi w 70. rocznicę urodzin, red. J. Popiel, Kraków 2009, s. 585-605.

Ego., Przed premjerq „, Miry Efros”. Rozmowa z Andrzejem Markiem, „Republika” 1929, nr 169, s. 4.

Finkelstein L., Oblicze literackie Jakuba Appenszlaka, „Nasza Trybuna” 1950, nr 3, s. 10.

Friszlender M., Czy potrzebny jest teatr polsko-żydowski. Artykuł dyskusyjny, „Nasz Przegląd” 1929, $\mathrm{nr} 236$, s. 7.

Jeske-Choiński T., Teatr żydowski, „Głos Warszawski” 1908, nr 160, s. 2.

Kamińska I., Nieporozumienia, „Teatr” 1955, nr 12, s. 18.

Kanfer M., Abraham Goldfaden. W 30-lecie śmierci, „Nowy Dziennik” 1938, nr 65.

Kanfer M., Gościnne występy Trupy Wileńskiej „Święty płomien’” Somerset Maughana. Reż. J. Szigarin, „Nowy Dziennik 1931, nr 119.

Kanfer M., Kiedy wreszcie przestaniemy mówić o ,żargonie żydowskim”? Na marginesie recenzji z przedstawień Trupy Wileńskiej, „Nowy Dziennik” 1931, nr 121, s. 11.

Kanfer M., Kilka stów odpowiedzi wileńskiemu Togowi, „Nowy Dziennik”, 1928, nr 348, s. 3.

Kanfer M., O sanację teatru żydowskiego w Polsce, „Nowy Dziennik” 1931, nr 139, s. 10-11.

Kanfer M., Żydowski Teatr Artystyczny. „Opowieść o siedmiu powieszonych” L. Andrejewa, „Nowy Dziennik” 1924, nr 140, s. 3.

Korenfeld M., Ghettowcy, Warszawa 1916, s. 11-14.

Kuberczyk T., Przedstawienia purimowe, „Pamiętnik Teatralny” 1992, nr 1-4, s. 21-49.

Kuligowska-Korzeniewska A., Pierwsze przedstawienia żydowskie w Lodzi, [w:] Łódzkie sceny żydowskie, red. M. Leyko, Łódź 2000, s. 15-38.

Kydryński L., Odwiedziny teatralne, „Przekrój” 1955, nr 526, s. 11.

M.K., Pod adresem p. Dżeni Lowicz i p. Lewina, „Nowy Dziennik” 1938, nr 198, s. 9.

M.K., Teatr Goldfadenowski - teatrem żydowskim. Z rozmowy z Zygmuntem Turkowem, „Nowy Dziennik" 1939, nr 107, s. 8.

Marek A., Wyjaśnienie p. Marka, „Nasz Przegląd” 1929, nr 207, s. 8. 
Najman J.M., ,,Der gojlem” po polsku, „Hajnt” 1928, nr 128, s. 9.

Nik., Warszawskie żydki, „Postęp” 1907, nr 152, s. 1.

Piasecki S., ,Hamlet” $i$, Cyrulik sewilski”, „Prosto z mostu” 1939, nr 16, s. 8.

Pierrot, Między wierszami. Czy powinien istnieć teatr „polsko-żydowski”, „Nasz Przegląd” 1929, nr 272, s. 5.

Podskocz J., Czy potrzebny jest teatr polsko-żdowski. Artykut dyskusyjny, „Nasz Przegląd” 1929, nr 256, s. 4.

Prokop-Janiec E., Mojżesz Kanfer a teatr jidysz, [w:] Teatr Żydowski w Krakowie. Studia i materiały, red. J. Michalik, E. Prokop-Janiec, Kraków 1995, s. 125-150.

Red., Korespondencja „Izraelity”, „Izraelita” 1883, nr 36, s. 292

Sandauer A., Na marginesie „,Snu o Goldfadenie”, „Przegląd Kulturalny” 1954, nr 50, s. 5.

Shmeruk Ch., Hebrew-Yiddish-Polish. Trilingual Jewish culture, [w:] The Jews of Poland between the world war, red. Y. Gutman, E. Mendelshon i in., Hannover London 1989, s. 283-311.

Słonimski A., „,Zemsta” w Ateneum, „Wiadomości Literackie” 5 października 1930, nr 353, s. 4.

Słonimski A., Kronika tygodniowa, „Wiadomości Literackie” 1929, nr 47, s. 11.

Słonimski A., Teatr Szkarlatna Maska: „Dybuk”, legenda dramatyczna w 3 aktach Szymona Anskiego; wolny przekład i inscenizacja Andrzeja Marka; reżyserowat thumacz; dekoracje wykonat Józef Wodyński, „Wiadomości Literackie” 1925, nr 75, s. 5.

Suesser J., Kilka słów o żargonie i teatrze żydowskim, „Izraelita” 1890, nr 25, s. 245-246.

Suesser J., Kilka stów o żargonie i teatrze żydowskim (ciag dalszy), „Izraelita” 1890, nr 26, s. 255-256.

Suesser J., Kilka stów o żargonie i teatrze żydowskim (dokończenie), „Izraelita” 1890, nr 27, s. 266-267.

Szacki J., ,Zloty Róg”, „Nasza Trybuna” 1950, nr 3.

Szacki J., Najstarsze dzieje żydowskiego teatru w Warszawie, thum. T. Kuberczyk, „Pamiętnik Teatralny" 1992, nr 1-4, s. 175-186.

Taub M., Abraham Goldfaden i teatr żydowski, thum. S. Wojnicki, „Pamiętnik Teatralny” 1992, nr 1-4, s. 57-70.

Turkow J., Di 'kemfer' far jidiszer kultur, „Literarisze Bleter” 1929, nr 36, s. 1-2.

Turkow J., Jidisz teater on jidisz, , Literarisze Bleter” 1929, nr 33, s. 641

Weichert M., Jidiszkejt in teatrer, tłum. M. Bułat, „Literarisze Bleter” 1930, nr 35, s. 655.

Weining N., Mity jidyszyzmu, „Miesięcznik Żydowski” 1932, s. 532.

Zastępca, Scena polsko-żydowska, „Nasz Przegląd” 1929, nr 203, s. 6.

\section{Jewish weed or a bridge of reconciliation? Images of Jewish theater in Poland in Polish and Jewish press}

This article discusses the various stereotypes of Jewish theater in Poland presented in the Polish and Jewish press (printed in Polish and Yiddish languages). It analyses the influence of Polish-Jewish relations upon constructing these imagines. It focuses both on positive and negative visions of Jewish theater in Poland.

Keywords: Antisemitism, Jews, Jewish theatre, Yiddish, newspapers, stereotypes 